\title{
ARTES, PARA A DIDÁTICA DA HISTÓRIA
}

Luiz Giani*

\section{RESUMO}

Um exame das relações entre arte e ensino da história contidas no livro didático público "História: ensino médio", do Paraná, resultou em seis grupos de arte, organizados por modalidade: música, literatura, artes visuais, teatro, dança e cinema. A música recebe atenção especial, no gênero orquestral, por apresentar um desafio maior para historiadores, livros didáticos, professores de história e da arte. Um breve perfil da história social da música é um alerta sobre a importância das relações históricas entre música e ideologia: o leitor é conduzido até a guerra ideológico-musical, após a segunda guerra mundial, entre movimentos que se fizeram antagônicos, de um lado, a música nacionalista "progressista" e, de outro, a vanguarda musical, especialmente, o dodecafonismo. Embora as pesquisas historiográficas tenham avançado, o livro didático ainda se encontra tímido, distante dos resultados das pesquisas. Pelos usos que o ensino da história possa fazer de cada arte, somente o compromisso com a emancipação humana omnilateral transforma a música e cada arte em conteúdo da história, recurso didático da história e forma de linguagem da história. Nenhuma arte permanece ausente desta dimensão, sem ferir a necessidade humana, universal, de todos os homens, sem exceção.

Palavras-chave: artes, história, ideologia, livro didático

\section{THE ARTS FOR DIDACTICS IN HISTORY}

\begin{abstract}
An analysis on the relationship between Art and the teaching of History, which is extant in the Paraná, Brazil, government textbook History: Secondary School Teaching provided six Arts groups, namely, Music, Literature, Visual Arts, Drama, Dancing, Cinema. Music is highlighted within the orchestra genre due to the fact that it is a big challenge for historians, textbooks writers and teachers of History and Arts. A brief history of the social history of Music insists on the importance of the historical relationships between Music and Ideology. In fact, the reader is invited to reflect on the ideological-musical struggle between antagonistic movements, after the II World War, or rather, 'progressive' nationalist music, on the one hand, and musical vanguardism, mainly dodecaphonism, on the other. Although research in historiography has made enormous progress, the textbook still lags behind, maintaining a distance from current research. Through the uses that History teaching may retrieve from Art and through the commitment with omnilateral human emancipation, all types of Art acquire History's structuring contents, didactic resources and language form. No one type of Art may be excluded without damaging universal human needs, without any exception.
\end{abstract}

Keywords: Arts; History; ideology; textbook.

\section{INTRODUÇÃO}

O objetivo principal deste ensaio consiste no exame das relações entre arte e ensino da história contidas no livro didático público "História: ensino médio", do Paraná. Inicialmente, apresentamos três formas de inserção da arte no ensino da história: conteúdo 
da história, recurso didático e linguagem da história. A partir do exame do livro didático "História: ensino médio", do Paraná, organizamos seis quadros das relações entre arte e história, por modalidade: música, literatura, artes visuais, teatro, dança e cinema. Nas seções finais, apresentamos algumas contribuições sobre a música.

Este ensaio tem como fundamento o princípio da arte como necessidade e potencial humano universal. A corrupção deste princípio não foi exclusividade do nazi-fascismo. Sob capitalismo tardio, amplia-se a estetização da barbárie. A humanidade "tornou-se suficientemente estranha a sim mesma, a fim de conseguir viver a sua própria destruição, como um gozo estético de primeira ordem. Essa é a estetização da política, tal como a pratica o fascismo. A resposta do comunismo é politizar a arte" (BENJAMIN, 1975: 341). Parafrasenado o pensamento de Benjamin, a atual servidão voluntária está em estado de gozo estético, encantada pelas promessas cumpridas de vida boa e bela, o grande espetáculo que a dominação oferece às grandes massas através da técnica, do progresso e da estetização da vida.

Se a dominação estetiza a vida, cabe à própria arte denunciar a dominação e seu projeto de estetização, um simulacro tornado realidade. Trata-se de politizar a arte contra a barbárie. Trata-se de estetizar a história contra a dominação, enquanto a dominação estetiza a guerra, a indústria cultural e a vida servil. Benjamin não viveu para ver como a poesia dos futurismo fascista pressagiou o atual "gozo estético", tal como o da invasão do Iraque oferecida para o prazer do grande público da TV (90\% da população americana foi favorável à invasão), ao vivo, como um megaespetáculo de videogame, no cenário noturno das cidades incendiadas e dos raios cortantes do fogo dos foguetes e artilharias.

As esperanças de Benjamin em uma cultura operária esclarecida, em que o cinema teria papel importante na educação das massas, o capitalismo tratou de dissipá-las.

A educação dos sentidos, como forma de emancipação humana, já era um tema primordial nos "Manuscritos econômicos e filosóficos" (1844), de Marx. Sob o capitalismo tardio, agravaram-se as questões da sensibilidade humana. As transformações sociais provocaram um declínio do economicismo e exigiram estudos sobre a cultura e a arte, como nas correntes que se seguiram a Plekhanov, Lukács, Gramsci, Benjamin, Adorno, Marcuse, Vallon, Vigotsky, Goldman, Fischer, Hobsbawm, Hauser, Heller, Bourdieu e Eagleton, entre muitos outros, para citar apenas os estrangeiros. Os frankfurtianos, observando as nações industrializadas mais avançadas, concluíram que a "zona de conflito" havia se deslocado das relações entre trabalho e capital para outras esferas, da cidadania, política, cultura e arte. A classe operária estava se contentando com as promessas de vida boa e bela que o capitalismo tardio começou a cumprir, um substituto para grande parte das promessas do socialismo. Por meio século, da década de 1930 até seu falecimento (1979), Marcuse incomodou-se com a dificuldade da humanidade em libertar-se de uma sociedade totalitária que passou a oferecer fartura e qualidade de vida:

Em relação a hoje e à nossa própria condição, creio que estamos diante de uma situação nova na história, porque temos que ser libertados de uma sociedade rica, poderosa e que funciona relativamente bem... O problema que enfrentamos é a necessidade de nos libertarmos de uma sociedade que desenvolve em grande medida as necessidades materiais e mesmo culturais do homem - uma sociedade que, para usar um slogan, cumpre o que prometeu a uma parte crescente da população. E isso implica que enfrentamos a libertação de uma sociedade na qual a libertação aparentemente não conta com uma base de massas. (MARCUSE, citado por BAUMAN, 2001: 23) 
O estudo da natureza humana, considerando o potencial humano para a práxis da sua emancipação, nos coloca frente a uma série de capacidades humanas universais, que exigem a educação e o cultivo ilimitado dos sentidos. A educação dos sentidos é tão importante quanto a educação do entendimento. Marx e Engels não se esqueceram da educação do homem total, um dos temas primordiais da obra "Sobre literatura e arte":

O homem apropria-se do seu ser universal de uma maneira universal, portanto, como homem total. Todas as suas relações humanas com o mundo, isto é, ver, ouvir, cheirar, ter paladar, tato, pensar, olhar, sentir, querer, agir, amar, em suma, todos os órgãos da sua individualidade... (...) A apropriação da realidade humana, a maneira como esses órgãos se comportam diante do objeto, constitui a manifestação da realidade humana. (MARX-ENGELS, 1979: 21).

O trecho, acima, Marx o escreveu, originalmente, sob o título "propriedade privada e comunismo", uma seção do terceiro manuscrito (MARX, 2006: 141).

\section{USOS DA ARTE, NO ENSINO DA HISTÓRIA}

Escolhemos alguns prismas, através dos quais a arte se relaciona com a metodologia e didática da história. Nesse esforço de classificação, delineamos três formas de uso da arte, na disciplina história: a) Arte como estetização da escrita da história; b) Arte como conteúdo estruturante, no ensino da história; c) Arte como recurso didático, no ensino da história.

\section{Arte como estetização da escrita da história}

A ficcionalização da história é uma questão que vem incomodando a ciência da história devido, especialmente, às transformações sociais, no capitalismo tardio, que colocam em cheque antigos valores do cientificismo. Quando se argumenta que a história é um domínio dos fatos, contra a fantasia e a ficção, a questão não termina aí. A própria escrita da história vem recorrendo, nos textos científicos e nos livros didáticos, a uma espécie de estetização da sua linguagem.

Marx estetizava a linguagem d" "O Capital", pela sua estilística ávida por recursos da linguagem de sentido figurado. Lançada a primeira edição inglesa, de 1867, um jornal inglês classificou o estilo de Marx como sendo de "peculiar encanto" (charm). Um jornal russo elogiou sua "clareza" e "vivacidade acima do comum", uma linguagem contraposta à da maioria dos eruditos alemães, que escreviam livros em linguagem indigesta e árida.

Quanto mais se utilizam os tropos, mais estetizada fica a escrita da história. O tropo, palavra proveniente do grego, tropo, pelo latim tropus, significa giro, desvio, volta. Trata-se do emprego da palavra ou uma expressão em sentido figurado. Além das figuras de palavras ou tropos (alegoria, alusão, antífrase, antonomásia, catacrese, eufemismo, metáfora, metonímia, sinédoque, etc.), há figuras de construção ou de sintaxe (anacoluto, anáfora, assíndeto, quiasmo, elipse, hipérbato, pleonasmo, repetição, silepse, tautologia, zeugma, etc.) e figuras de pensamento ou de estilo (antítese, enumeração, exclamação, gradação, hipérbole, lítotes, perífrase, preterição, prosopopéia, reticências, etc.). Tropo, entre os gregos, significava também a impossibilidade de se atingir a verdade. Eram argumentos pelos quais os céticos sustentavam que era impossível atingir a verdade.

O tropo facilita a comunicação, evoca imagens através de símbolos, confere mais força e colorido à linguagem. Apenas para exemplificar, um pequeno levantamento de 
figuras de linguagem contidas em prefácios e posfácios d" "O Capital" é suficiente para se ter uma idéia sobre o esmero estilístico de Marx, sua predileção pelo estilo figurado. As referências, entre parêntesis, correspondem ao Livro 1 e número da página (MARX, 1975):

Além dos males modernos, oprime a nós alemães uma série de males herdados, originários de modos de produção arcaicos, caducos, com seu séquito de relações políticas e sociais contrárias ao espírito do tempo. Somos atormentados pelos vivos e, também, pelos mortos. Le mort saisit le vif (O morto tolhe o vivo.) (Livro 1: 5)

Hoje em dia, o próprio ateísmo não passa de um pecadilho, em confronto com a blasfêmia de criticar as relações consagradas de propriedade. (Livro 1: 6)

...do outro lado do Atrântico, Mr. Wade, vice-presidente dos Estados Unidos, declara em comícios, que, depois de abolida a escravatura, entra na ordem do dia a transformação das relações do capital e da propriedade da terra. São os sinais dos tempos, que não se deixam encobrir por mantos purpúreos ou negras sotainas. Não significam a ocorrência de milagres amanhã. Eles mostram, como as classes dominantes já começam a pressentir que a sociedade atual não é um ser petrificado, mas um organismo capaz de mudar, constantemente submetido a processo de transformação. (Livro 1: 7).

E quanto aos preconceitos da chamada opinião pública, torno minha, agora como dantes, a máxima do grande Florentino:

Segui il tuo corso, e lascia dir le genti!

(Segue teu rumo e não te importes com o que os outros digam!)

(Prefácio da $1^{a}$ Edição. Londres, 25 de julho de 1867, Livro 1: 7)

Os embusteiros palradores da economia vulgar censuram a linguagem e o estilo de minha obra. Ninguém pode criticar seus defeitos literários mais severamente do que eu mesmo. Não obstante, para proveito e alegria desses cavalheiros e de seu público, citarei dois pareceres: um inglês e um russo. O periódico "Saturday Review", de orientação hostil às minhas idéias, diz, ao noticiar a primeira edição alemã: "O estilo empresta até aos problemas econômicos mais áridos um peculiar encanto (charm)". O "Jornal de São Petersburgo", na sua edição de 20 de abril de 1872, observa, entre outras coisas: "A exposição, excetuadas algumas partes demasiadamente especializadas, distingue-se por estar ao alcance de todas as inteligências, pela clareza e, apesar da altitude científica da matéria, pela vivacidade acima do comum. A esse respeito, não existe a menor semelhança entre o autor e a maioria dos eruditos alemães, que escrevem seus livros numa linguagem tão indigesta e tão árida, que faz estourar a cabeça dos seres humanos normais". Se o mesmo efeito explosivo ocorre com os leitores da atual literatura catedrática alemã, nacional e liberal, não será na cabeça. (Posfácio da $2^{\mathrm{a}}$ edição, Londres, 24 de janeiro de 1873, Livro 1: 12-13)

Não há estrada real para a ciência, e só têm probabilidade de chegar a seus cimos luminosos, aquêles que enfrentam a canseira para galgálos por veredas abruptas. (Prefácio da Edição Francesa, em 18.03.1972, Livro 1: 19)

(MARX, 1975: 119)

Além da estetização da escrita da história, como exposto acima, variadas formas da arte possibilitam um quadro amplo de estetização da linguagem escrita e falada da história, em criações dos próprios alunos: a história em linguagem teatral, os desenhos, as histórias 
em quadrinhos e, através da música, as leituras de texto em forma de rap e a criação de narrativas cantadas (nos modos de samba-enredo, milonga, embolada, rap e, como na cantoria nordestina, o desafio), entre muitas outras formas da arte.

\section{Arte como conteúdo estruturante, no ensino da história}

Literatura e artes visuais são as mais contempladas, no livro didático público "História: ensino médio", do Paraná. Cinema e teatro ocupam um espaço muito pequeno. Música e a dança ocupam um espaço tão minúsculo, que parecem excluídas.

A departamentalização do conhecimento e da arte separa os conteúdos em verdadeiros currais, desarticulados entre si. Assim, a literatura consegue ser mais estranha aos livros didáticos de arte do que aos livros didáticos de história. Os "Parâmetros Curriculares Nacionais: Arte" e enorme quantidade de livros didáticos de arte restringem a arte a quatro troncos: artes visuais, teatro, música e dança. Fica reservado para a literatura um departamento exclusivo, em disciplina isolada, geralmente, língua portuguesa.

Ora, a ciência da história pode, a um só tempo, juntar o que as demais disciplinas separam. No combate à fragmentação que impera na chamada "pós-modernidade", ela pode reconhecer as conexões entre todas as ciências e artes, bem como entre estas e a sociedade.

Não são apenas os "Parâmetros Curriculares Nacionais: Arte" que negam a interdisciplinaridade que dizem incentivar. Se a literatura está alijada dos PCN/Arte, o mesmo acontece com as artes em geral, quando tornadas secundárias em cursos de formação de professores excessivamente confinados em conteúdos de artes visuais, mesmo quando a nomenclatura do curso seja universal: Educação Artística. As histórias de cada arte são férteis, quando abordadas em suas histórias específicas, livros separados: "história da arte" (é assim que se chama a história das artes visuais, em tratados, compêndios e livros didáticos!), história da literatura, história da música... Nos cursos de graduação em história, há currículos em que a história da arte não está incluída ou, se anteriormente incluída, foi eliminada.

A história tem ainda muito a aprender com a arte e vice-versa. Falta a todas as artes, nos livros didáticos, valer-se mais dos estudos históricos de conjuntura, para que se entenda a arte como produto social e produtora da sociedade. Por sua vez, a história tem também sérias dificuldades quando entra em domínios em que os historiadores, de um modo geral, não têm familiaridade, como a linguagem musical, o que dificulta e impede a mediação, a construção dos elos explicativos entre arte e história, arte e sociedade.

\section{Arte como recurso didático, no ensino da história}

Considerada a arte como mero apoio, instrumento auxiliar, talvez este seja o prisma pelo qual a arte tenha sido utilizada com maior freqüência, como facilitadora da aprendizagem. Trata-se do apoio que o ensino da história procura nas atividades, meios e materiais da arte: letras das músicas, trechos de literatura e poesia, fotografias de obras de artes visuais, filmes, atividades de música, dramatização, dança, etc. A bibliografia sobre atividades artísticas para a didática da história é ainda pequena. Em outras disciplinas, cresce também a preocupação metodológica com o entrosamento com a arte, como o método da "geografia em canção".

Entre as mais recentes contribuições, encontra-se a obra do historiador Marcos Napolitano, "Como usar o cinema na sala de aula", com um capítulo especial sobre cinema 
para as aulas de história (NAPOLITANO, 2008) (para acessar a obra, clique no site, ao final deste ensaio).

\section{A ARTE E O LIVRO DIDÁTICO PÚBLICO "HISTÓRIA: ENSINO MÉDIO", DO PARANÁ}

No livro didático público "História: ensino médio", do Paraná, os recursos didáticos de cada arte aparecem fragmentados, pontilhando os dezenove capítulos, a critério dos sete autores de capítulos. Imaginamos que poderíamos contribuir para melhorar a relação entre arte e ensino da história, da seguinte forma: escolher uma arte, por exemplo, música, e percorrer os capítulos do livro didático, rastreando as ações relativas à música; em seguida, realizar o mesmo com a literatura, e assim por diante. Deste trabalho de organização e exposição resultam seis quadros, por modalidades da arte, onde o leitor pode encontrar um painel de conteúdos de cada arte e avaliar os graus de profundidade alcançados no campo das relações história/arte, em cada modalidade.

\section{Música}

O livro didático é totalmente omisso em recursos didáticos musicais. Não sugere atividades como cantar e apreciar música. Entendida esta em seu sentido estrito, música não é letra. Música são sons, sem palavras. A letra da música, por si só, não é canção. Canção é melodia acompanhada da palavra, letra, poema. A utilização da palavra canção implica em referências aos elementos próprios da música. Retiradas as letras, poesias, textos literários, etc., que fazem parte dos gêneros das canções, óperas, operetas, musicais (do teatro e do cinema), etc., permanece a essência da música em seus elementos materiais exclusivos: melodia, ritmo, harmonia, instrumentação, orquestra, etc. A música exclusivamente instrumental, como a das orquestras e bandas, é o gênero, por excelência.

No capítulo "2.4. O Estado imperialista e sua crise", de Altair Bonini e Marli Francisco, um texto de crítica à dominação cultural imperialista, "A indústria cultural e as nações imperialistas", estimula a atividade solicitada aos alunos. Pede-se a eles para citar exemplos da indústria cultural no campo da música, além de filmes, moda e linguagem.

O capítulo "3.2. Relações culturais nas sociedades grega e romana na antiguidade: mulheres, plebeus e escravos", de Fábio Cardoso, apresenta a letra de "As mulheres de Atenas" (Chico Buarque e Augusto Boal) e um programa de atividades exclusivamente cognitivas, sem as ações de sensibilização musical que atuam sobre o afeto, as emoções.

Da mesma forma, não se pede para cantar, no capítulo “3.6. Movimentos sociais, políticos e culturais na sociedade contemporânea: é proibido proibir?" Bonini pede, apenas, que o aluno leia a letra da música "É proibido proibir", de Caetano Veloso, e discuta com seus colegas o significado que a música (a letra?) teve para os jovens do passado e o significado que ela tem para os jovens de hoje em dia. "Geração coca-cola" (Renato Russo) e "Apesar de você" (Chico Buarque) ilustram o texto que Bonini organizou sob o tema "A contestação dos jovens pela música". Este texto, em todo o livro, é o único momento de história da música. Não há como fugir do hábito de cantarolar, quando se fala de rock, música de protesto, tropicalismo e hip hop. São seis páginas dedicadas à história da música, que Bonini situa no contexto da didatura de 64, cercando manifestações musicais de movimentos da juventude, sob os três primeiros governos ditatoriais (Castelo Branco, Costa e Silva e Médici). Para a história da música universal, o autor organizou um texto sob o título "O rap e o movimento hip hop", com rápidas referências à linguagem 
musical. Bonini trata da origem do rap, passando pela sua chegada aos jovens brasileiros, nos anos 80, e importantes manifestações recentes, como o Projeto Quixote, na zona sul de São Paulo, ligado à USP e iniciado em 2001. Como atividade, o autor pede que o aluno relacione a realidade com os projetos dos jovens das periferias das grandes cidades, com base nos textos "História do rap" e "Graffiti e educação" (sobre o Projeto Quixote).

Para o capítulo "3.7. Urbanização e industrialização na sociedade contemporânea", Sueli Dias redigiu um breve texto, referindo-se especialmente à música, e lançou mão de um texto de Hobsbawn sobre o confinamento da "grande arte" a guetos de elite: o acesso ao teatro, ópera, museus, galerias de arte, literatura e prosa, pertencia "esmagadoramente aos que tinham pelo menos educação secundária", diz Hobsbawm. A indústria da diversão de massa provocou o declínio desse "grande estilo" (a "grande arte" que floresceu no século XIX e sobreviveu na primeira metade do século XX) e contaminou a própria elite, que também se envolveu na diversão de massa, certamente desde o triunfo do rock. Para tornar a diversão de massa adequada ao gosto da elite, os intelectuais sem dúvida deram-lhe um "toque cerebral". Como atividade didática, sob o tema "A tecnologia, a urbanização e a arte", pede-se que o aluno analise e discuta o texto de Hobsbawm. O aluno deve criar uma narrativa sobre a cultura transmitida pela indústria de diversão em massa e comparar o rock com o hip-hop: quando e onde surgiram, que grupos protagonizaram estes estilos, que temas e mensagens transmitem. Finalmente, a autora propõe um debate em sala para discutir sobre as condições e organização dos locais de lazer e cultura da cidade. As críticas e sugestões devem ser divulgadas pelos alunos.

\section{Literatura}

Em "1.2. O mundo do trabalho em diferentes sociedades", Cardoso recorre ao poema de Brecht, "Perguntas de um operário letrado".

Uma poesia de Mary Collier enriquece o tema sobre o trabalho da mulher, no capítulo "1.3. A construção do trabalho assalariado", redigido por Siumara Sagati.

No capítulo "2.2. O Estado e as relações de poder: formação dos estados nacionais", Fábio Cardoso vai buscar nos poemas "Canção do exílio" e "I-Juca Pirama" exemplos de nacionalismo romântico, indianista, em que Gonçalves Dias retrata o índio "com sentimentos e atitudes artificiais, com aspectos europeus". A literatura de época, romântica, contribuiu para a construção da idéia de nação brasileira, na qual os indígenas eram vistos "de forma idealizada, como heróis, semelhantes aos cavalheiros medievais". Como atividades, Cardoso pede ao aluno um relato sobre "a visão de Gonçalves Dias em relação à pátria e aos indígenas descritos nos poemas"; apresenta as letras do "Hino Nacional do Brasil" e do "Hino da Independência do Brasil" e solicita aos alunos que busquem no dicionário o significado das palavras desconhecidas e descrevam como os hinos representam a pátria, a liberdade e a figura do herói.

No capítulo "3.2. Relações culturais nas sociedades grega e romana na antiguidade: mulheres, plebeus e escravos", Fábio Cardoso insere um trecho da peça "Lisístrata", do comediante grego Aristófanes, e a letra da canção "As mulheres de Atenas" (Chico Buarque e Augusto Boal). Solicita ao aluno que discuta com seus colegas sobre as argumentações defendidas em "Lisístrata", em que Aristófanes denuncia as ambições da guerra. Após um breve texto intitulado "A imagem da mulher grega nas Artes", Cardoso propõe ao aluno que leia trechos da "Odisséia", de Homero, e faça um relato das características de Penélope. Como atividade relacionada com o texto "As mulheres na sociedade grega", pede-se ao aluno que leia os fragmentos da canção "Mulheres de Atenas" e pesquise no dicionário os significados das palavras desconhecidas. 
O autor do capítulo coloca para o aluno o desafio de identificar as condições das mulheres da antiguidade grega, comparadas com as condições das mulheres da década de 1970, momento em que a letra da canção foi escrita. Finalmente, o aluno deve escrever uma narrativa histórica, comparando as diferenças e semelhanças, entre as duas situações.

A violência contra os camponeses que se rebelaram na Normandia, em 996, é relatada no poema épico "O Romance de Rolando", de Robert Wace, como parte do capítulo “3.3. Relações culturais na sociedade medieval européia: camponeses, artesãos, mulheres, hereges e doentes", de Sueli Dias, Um fragmento literário de "Yvain", conto de Chétien de Troyes, retrata o sofrimento das tecelãs de seda, na Inglaterra. A atividade dos alunos está definida na pergunta: "que relações de trabalho enfrentavam as mulheres, cujo lamento está citado no fragmento do conto?"

Um trecho do "Decameron", de Boccaccio, sobre aspectos sociais da peste em Florença, em 1348, é de um realismo assustador, que merece ser transcrito, aqui: "O desastre lançara tanto pavor no coração dos homens e das mulheres que o irmão abandonava o irmão, o tio o sobrinho, a irmã o irmão, amiúde mesmo a mulher o marido. E o que é mais forte e quase inacreditável: os pais e as mães, como se seu filhos não mais lhes pertencessem, evitavam vê-los e ajudá-los" (Boccaccio). Dias conclui o capítulo, solicitando aos alunos que façam um debate em torno da comparação "entre a exclusão a que eram submetidos os doentes na Idade Média e os preconceitos com que são tratados os portadores de doenças contagiosas, nas sociedades contemporâneas". Após o debate, os alunos são convidados a escrever uma narrativa histórica sobre o tema.

O capítulo "3.4. Movimentos sociais, políticos, culturais e religiosos na sociedade moderna", de Marli Francisco, contem três textos literários: uma oração guarani e trechos do "Romanceiro da Inconfidência" (Cecília Meireles) e da "Utopia" (Thomas Morus). Para a oração guarani, voltada para a espera da "Grande Palavra", Francisco propõe uma comparação entre esta oração e as idéias presentes no texto de Pierre Clastres, em que este fala do discurso dos karai, profetas indígenas da América Latina. Esses profetas exortavam os indígenas a abandonar a terra má e dirigir-se à Terra Sem Males, "lugar de repouso dos deuses, onde as flechas partem sozinhas à procura da caça, onde o milho cresce sem que ninguém cuide dele...". Feita a comparação entre a oração guarani e o texto de Clastres, o aluno escreve uma narrativa histórica tendo como tema a religiosidade guarani.

"Atrás de portas fechadas, à luz de velas acesas", fragmento do poema "Romanceiro da Inconfidência", de Cecília Meireles, conduz o aluno a idéias e fatos que devem ser comparados com o conteúdo de um texto sobre os objetivos da Inconfidência Mineira. Francisco solicita ainda que o aluno procure no dicionário o significado das palavras que ele desconhece. O fragmento da "Utopia", de Thomas Morus, contem uma crítica à expulsão dos camponeses de suas casas. Esgotados seus fracos recursos, o que lhes restam?, pergunta Morus. Resta-lhes "o roubo, e depois, o enforcamento, segundo as regras". Para este tema, Francisco propõe a seguinte atividade: "compare as permanências e mudanças entre os fatos apresentados no texto de Morus com a realidade em que vivem os pequenos agricultores do Brasil dos séculos XX e XXI. Considere seus respectivos contextos históricos". Em seguida, o aluno lê um texto de Karl Marx sobre a expropriação dos camponeses e compara o texto de Marx com o de Morus.

Sob o título "Iluminismo: as luzes da razão na modernidade", o aluno lê uma página de Francisco sobre a "Enciclopédia", de Diderot e d’Alembert. A autora solicita ao aluno que, após a leitura da página, observe também o desenho "Frontispício da Encyclopédie" (1772) e "faça uma leitura desta imagem apontando o que ela representa e descreva suas observações a partir do contexto de sua produção". 
Para o entendimento das questões abordadas no capítulo “3.5. Urbanização e industrialização no século XIX”, Altair Bonini foi buscar apoio em fragmentos extraídos da literatura naturalista de Emile Zola, bem como da obra de um precursor do realismo, Victor Hugo, e da crítica literária de Marshall Berman sobre a modernização. Na seção intitulada "A nova realidade e suas impressões na Literatura e na Arte" Bonini recorre a fragmentos de "Os miseráveis", de Victor Hugo; "Tudo que é sólido desmancha no ar: a aventura da modernidade", de Marshall Berman; e "Germinal", de Emile Zola. Como atividade, Bonini diz que "os romances podem ser uma boa fonte de pesquisa" e pede ao aluno para ler os fragmentos de "Os Miseráveis" e "Germinal" e destacar as informações que os autores transmitem sobre a vida dos trabalhadores urbanos do século XIX. Finalmente, o aluno compara aquela vida com a vida dos trabalhadores durante a modernização. Bonini pede ao aluno que "veja a opinião do crítico literário Marshall Berman sobre o período da modernização através dos pensamentos de Marx, contemporâneo dos romancistas do Realismo".

Com a letra da canção "Geração coca-cola", de Renato Russo, Bonini abre o capítulo "3.6. Movimentos sociais, políticos e culturais na sociedade contemporânea: é proibido proibir?" e pede que o aluno discuta as seguintes questões:

\begin{abstract}
A partir de 1950, muitas formas de resistência surgiram contra os governos autoritários, o sistema capitalista e a globalização. Quem foram os sujeitos desses movimentos? A ordem estabelecida pode ser contestada? Quem a estabeleceu? Quem deve se submeter às pessoas que ditam esta ordem? Alguém deve obedecê-las? Você conhece algum grupo que luta por um mundo melhor e por direitos? São estas questões que você poderá discutir...
\end{abstract}

A seção intitulada "A Revolução jovem”, de Bonini, é, certamente, o texto mais fecundo de história da arte de todo o livro didático público "História: ensino médio", do Paraná. Seus conteúdos literários estão misturados a conteúdos referentes à música, dança e artes visuais, em abordagem interdisciplinar sobre rock, canção de protesto, tropicalismo e hip hop. A seção contém textos de Bonini, entrecortados com um texto de Hobsbawm e outro, extraído da internet, além das letras das canções "Apesar de você" (Chico Buarque) e "É proibido proibir", de Caetano (com um pedido aos alunos, para debater o significado do poema para os jovens de ontem e hoje). Os textos vão da música, "A contestação dos jovens pela música", passando por " 68 , o ano em que os profetas falharam", de Hobsbawm, até a "História do rap" (extraído da internet), o "Movimento Hippie" e "O Rap e o Movimento Hip Hop", ambos de autoria do próprio Bonini. Para o debate, Bonini pede ao aluno que leia a letra de "É Proibido proibir" e discuta com seus colegas o significado que essa música (Bonini refere-se, certamente, à letra) teve para os jovens do passado e o significado para os jovens de hoje em dia.

Sueli Dias, no capítulo "3.7. Urbanização e industrialização na sociedade contemporânea" sugere uma atividade, sob o tema "A tecnologia, a urbanização e a arte". $\mathrm{O}$ aluno analisa um texto de Hobsbawm para, depois, discutir com o professor e os colegas. Dias pede a ele para redigir uma narrativa sobre a cultura transmitida pela indústria de diversão em massa, com base nos seguintes aspectos: uma comparação entre o rock e o hip-hop; quando e onde surgiram; grupos que protagonizaram estes estilos e temas e mensagens transmitidos. 


\section{Artes visuais}

São apenas ilustrativos os recursos visuais do "1.1. Conceito de trabalho": uma iluminura, com figuras de servos trabalhando, entre os séculos XII a XIV; retratos de Marx e Durkheim e uma fotografia de operários em linha de montagem.

O capítulo "1.2. O mundo do trabalho em diferentes sociedades" está repleto de fotografias: são bustos de Aristóteles e Sêneca, um calendário camponês do século XV, fotografias das pirâmides egípcias, ruínas do Coliseu, um castelo medieval, um templo asteca em Palenque, o palácio do governador asteca em Uxmal (Iucatã) e um prato maia em cerâmica policromada. Fábio Cardoso, autor do capítulo, aborda apenas a arquitetura em seu texto intitulado "Trabalho e arte nas sociedades pré-colombianas". Ficaria melhor se tivesse substituído a palavra arte por arquitetura, pois arquitetura não é a arte, mas, apenas, uma das artes. A palavra arte deve ser substituída por arquitetura, na seguinte proposta de pesquisa que o autor solicita ao aluno: "em livro de História da Arte, de História, na Internet e em revistas como National Geografic, sobre a arte dos Maias, Incas e Astecas, procure perceber em que se aproximam e em que se distanciam quanto à forma, à temática, aos materiais e à função. Apresente suas conclusões para a classe".

Como última atividade do capítulo, Cardoso pede ao aluno para observar as imagens das pirâmides egípcias, Coliseu de Roma e o castelo medieval, e produzir "uma narrativa histórica destacando como foi possível a construção destes monumentos, considerando a tecnologia dos períodos expressos, bem como o trabalho empregado na construção destes monumentos".

No capítulo "1.3. A construção do trabalho assalariado", de Siumara Sagati, as fotografias ilustram o conteúdo dos textos: uma operária em máquina de fiar de Hargreaves, a máquina a vapor de Watt, retratos de Augusto Comte e Saint-Simon, operários trabalhando na Fábrica Nacional de Tecidos Juta (1931) e o trabalho dos operários na Oficina de Latoeiro (Rio de Janeiro, 1908)

No capítulo "1.4. Transição do trabalho escravo para o trabalho livre: a mão de obra no contexto de consolidação do capitalismo nas sociedades brasileira e estadunidense", de Marli Francisco e Vanderleia Canha, o aluno tem acesso à aquarela "Engenho de cana", de Hércules Florence, e aos quadros do pintor e desenhista Debret, além de um retrato e breve biografia extraída da obra "Debret: cenas de uma sociedade escravista", de Raimundo Campos. Os quadros de Debret apresentados no livro didático são as litogravuras: "Barbeiros ambulantes", "Vendedor de palmitos", "O Colar de ferro", "Negros no tronco" e "Negros serradores de tábuas". O texto em que os quadros estão inseridos intitula-se "O Trabalho escravo no novo mundo". As autoras do capítulo pedem ao aluno para desenvolver atividades, a partir da análise dos quadros: personagens retratados, cenários e intenções do artista. "A partir desses documentos, o que você pode afirmar sobre o negro no Brasil naquele contexto histórico?", perguntam. Pedem para relacionar o contexto sócio-histórico da produção das imagens presentes nos quadros de Debret e Florence com os conteúdos das mesmas. Quais representações das relações de trabalho são propostas por Florence e Debret? Estas representações possibilitam que você perceba o motivo das várias revoltas escravas ocorridas no Brasil e no resto da América neste período? Por quê? Pede-se também aos alunos que, em grupo, pesquisem sobre a escravidão no mundo contemporâneo e montem um painel a ser apresentado para a escola.

No capítulo "1.5. Relações de dominação e resistência no mundo do trabalho contemporâneo (séculos XVIII e XIX)", um dos textos, reunindo narrativa de Sagati e outros autores, trata mais extensamente da participação da mulher, sob o título "As Revoluções e a luta pela igualdade. Manifestações femininas: a busca da cidadania". Com 
base nas três fotografias alusivas às "sufraguetes", Sagati solicita: "descreva os documentos (fotografias) apresentando o tipo de documento; época e sociedade a que se refere, personagens históricos representados, temática principal. Redija uma narrativa histórica tendo como referência a forma pela qual a temática está representada nas imagens presentes nos documentos".

"Mulheres conduzindo canhões" (quadro referente à marcha sobre Versalhes em 5 de outubro de 1789) é um quadro ilustrativo, que o aluno deve visualizar para realizar a seguinte atividade: "duas revoluções marcaram a história da cidadania das mulheres: a Americana (1776) e a Francesa (1789). Observe o quadro, leia os textos e aponte semelhanças e diferenças sobre o envolvimento feminino nos dois processos revolucionários".

O texto "A organização dos operários" recebeu quatro ilustrações. Uma, originalmente publicada em jornal da Inglaterra, com data de abril de 1848, revela que milhares de pessoas compareciam aos comícios do movimento cartista, assim chamado devido à Carta do povo que a classe trabalhadora dirigiu ao Parlamento Britânico. O expressivo "O quarto estado" (1902), de Giuseppe Pelizza da Volpedo, óleo sobre tela, retrata a massa dos trabalhadores em movimento de avanço (participantes de todas as idades, inclusive, uma operária com a criança no colo, na linha de frente). Este quadro é um importante marco na pintura dos movimentos de dominação e resistência no campo do trabalho, tema que dá título ao capítulo. Retratos de Bakunin e Marx revelam os líderes, respectivamente, do anarquismo e do socialismo.

O texto "Os jovens, a participação política e a cidadania" toca em diversas questões sociais, políticas e culturais, inclusive expressões artísticas, em diversas épocas. Os movimentos da juventude sempre produziram suas artes visuais, além da música, e também foram retratados na pintura e literatura de época: artes da "boêmia", dos Apaches, do "Wandervogel" ("Pássaro migrante"), etc. Como atividade, Sagati pede ao aluno para pesquisar fotografias e elaborar um dossier sobre o movimento operário no Brasil.

Para o capítulo "1.6. Urbanização e industrialização no Brasil”, Sagati selecionou dois quadros de engenho de cana, em litogravura de Koster e aquarela de Florence; diversas fotografias, desenhos, pinturas de cidades históricas e sua arquitetura: "Salvador", desenho/1625; foto do Pelourinho; uma vista da "Cidade Maurícia e Recife", em óleo sobre madeira de Franz Post, 1657; a "Ponte Maurício de Nassau", litografia, séc. XIX; fotografias de Ouro Preto e Mariana; "Vista da rua principal do Rio de Janeiro", por Thomas Ender; "Aceitação provisória da constituição de Lisboa", Rio de Janeiro, litografia de Debret; arquitetura e altar da igreja colonial de São Francisco de Assis, em São João Del Rei. Sob o tema "Vida urbana e industrialização no Brasil", a modernidade é ilustrada com a fotografia de uma locomotiva, alusiva à primeira estrada de ferro no Brasil, um bonde elétrico, fotos da "Companhia Siderúrgica Nacional" e uma refinaria de petróleo, fábrica do fusca no Brasil e dois desenhos em quadrinhos, em que um quadrinho dos Semteto contrasta com o quadrinho alusivo ao consumismo. A partir destes desenhos e dois textos sobre os problemas da moradia, Sabati solicita ao aluno que tire suas conclusões e faça um debate em sala de aula sobre os espaços urbanos no Brasil contemporâneo.

Sueli Dias ilustra o capítulo "1. 7. O trabalho na sociedade contemporânea" com fotografias relacionadas com taylorismo, fordismo, Mina de Morro Velho, Companhia Siderúrgica Nacional, greve geral de 1917, em São Paulo, Plenário do $1^{\circ}$ Congresso Nacional dos Sem-Terra (1985), operários em uma fábrica de automóvel e interior da fábrica da Mercedez-Benz, em Juiz de Fora, onde se vê, em primeiro plano, a montagem bruta em que $40 \%$ das atividades cabem aos robôs. 
As artes visuais do capítulo "2.1. O Estado nos mundos antigo e medieval", também redigido por Sueli Dias, são constituídas de vários mapas, uma fotografia das ruínas de Atenas e uma iluminura (sagração de um rei inglês, séc. XIV).

No capítulo "2.2. O Estado e as relações de poder: formação dos estados nacionais", Fábio Cardoso inseriu quadros de "Luiz XIV", óleo sobre tela de Rigaud; "Dom Pedro I", óleo sobre tela de Henrique José da Silva; o conhecido óleo sobre tela "Independência ou morte", de Pedro Américo; retrato de Gonçalves Dias; bandeira do império brasileiro e bandeira nacional. Em uma das atividades, Cardoso solicita ao aluno que analise as imagens das bandeiras: "quais representações podem ser percebidas nas bandeiras?". Em outra atividade, pede para o aluno observar o quadro de Pedro Américo e analisar como foi representada a figura do trabalhador e se a proclamação da independência do Brasil foi exatamente da forma apresentada no quadro. Em seguida, o aluno deve construir uma narrativa histórica, argumentando sobre estes questionamentos.

Sagati selecionou uma obra-prima, "A liberdade guiando o povo" (1831), de Delacroix, principal representante do romantismo pictórico, para ilustrar o capítulo "2.3. Relações de poder e violência no Estado". Como atividade do texto "As guerras revolucionárias e nacionais", a autora solicita uma leitura do quadro "A liberdade guiando o povo": tipo, autoria, época, personagens representados, e pergunta: a quais acontecimentos históricos o quadro se refere?

Rico em imagens, o capítulo contem ilustrações da batalha de Waterloo, batalha de Mars-La-Tour e cenas da $2^{\text {a }}$ Guerra Mundial: o cogumelo de fumaça da bomba nuclear de Hiroshima, grupo de crianças presas em Auschwitz, prisioneiros em campo de concentração, crianças protegendo-se de um ataque aéreo, mulheres russas em momento de ataque alemão sobre o território russo, desembarque do $1^{\circ}$ escalão da FEB na Itália.

O título "A Cara das guerras" - desde as guerras de ocupação colonial até as guerras atuais, que sucedem à guerra-fria - é ilustrado por uma fotografia da derrubada das torres gêmeas do World Trade Center, de Nova Iorque, em 11 de setembro de 2001.

O texto intitulado "A tortura...", ilustrado por uma fotografia da capa do livro "Brasil nunca mais", conta um pouco da história da repressão e tortura a que eram submetidos os presos políticos, na Ditadura Militar de 64, como a famosa Operação Marumbi, desencadeada em setembro de 1975, no Paraná. Um pequeno texto fala da arte dos cartuns e caricaturas, na resistência à ditadura. Uma charge de Henfil ilustra os comentários sobre sua participação nos movimentos de resistência e denúncia.

Atividades solicitadas por Sagati: a partir da análise da charge de Henfil, o aluno escreve sua opinião sobre a presença da censura e da tortura como restrições aos direitos do cidadão; leitura das imagens e texto sobre as guerras mundiais; montagem de mural sobre as guerras mundiais.

O capítulo "2.4. O Estado imperialista e sua crise”, de Bonini e Francisco, iniciase com as questões em torno de um cartaz da coca-cola, intitulado "Pretensões de conquista mundial": "para você, qual seria a mensagem desta imagem? Que relações são possíveis de estabelecer entre o produto anunciado e os líderes representados na imagem? No cartaz da coca-cola são colocados, lado a lado, Stálin, Lênin, Napoleão e outros chefes de império, com a seguinte frase: "only one launched a campaign that conquered the world" ("somente uma campanha lançada conquista o mundo").

Sob o texto intitulado "O ataque ao Império Estadunidense", há uma fotografia do ataque às torres gêmeas de Nova Yorque.

Sobre uma charge intitulada "Imperialismo", é formulada a seguinte atividade: analise a imagem "Imperialismo", registrando suas impressões quanto: a) o que representa 
o homem no centro da imagem? b) o que representam os fios em torno do homem? c) para você, qual a mensagem central da imagem? Justifique.

Algumas fotografias estão relacionadas com o nazismo ("Desfile no aniversário de Hitler"), a Conferência de Yalta (Churchill, Roosevelt e Stálin) e a crise do socialismo soviético (uma foto de Gorbatchev e outra, de cidadãos alemães destruindo o muro de Berlim, em 1989).

O texto "A arte nos regimes totalitários na Alemanha e Itália" contem referências às artes visuais, entre outras. Os autores comentam a utilização das diversas artes como meio para doutrinação ideológica e imposição das idéias do regime. A partir da foto "Desfile no aniversário de Hitler", pede-se que o aluno registre suas impressões em relação aos símbolos e sua disposição, aos militares e sua organização, aos expectadores. Após uma conversa com os colegas de classe, os alunos devem escrever uma narrativa histórica sobre como a cultura foi um recurso importante para os regimes totalitários.

A partir da leitura do texto "A indústria cultural e as nações imperialistas", Bonini e Francisco, pede-se ao aluno para construir uma narrativa histórica sobre a indústria cultural como meio para justificar a dominação do Estado imperialista sobre os povos dominados. Sobre a influência de produtos culturais de nações estrangeiras em nosso país, alterando hábitos culturais de parte da população, pede-se ao aluno para citar exemplos de filmes, moda, linguagem, música, e suas influências na sociedade brasileira.

Marli Francisco, autora do capítulo "2.5. Urbanização e industrialização no Paraná", ilustra o texto com poucos quadros, porem, significativos. De Debret, uma litografia intitulada "Soldados índios de Curitiba escoltando selvagens", isto é, índios cançando índios para o domínio colonial. O texto "As primeiras vilas e cidades do Paraná" contem referências à arquitetura e o quadro "Curitiba antiga: Rua das Flores nos tempos da Província”. Como atividade, pede-se que o aluno observe este quadro, considerando as permanências da organização da ocupação do espaço proposta no texto (povoamento e vias comerciais). Outros quadros: de Willian Lloyd, uma aquarela, "Vista geral de Antonina", de 1872; de Debret, a aquarela "Cidade de Castro", de 1827. Atividades: os alunos relacionam a aquarela de Antonina (Lloyd) com os textos e descrevem o modo de vida dos habitantes de uma cidade tropeira, a partir da aquarela "Cidade de Castro" (Debret).

“3.1. As cidades na história" é um capítulo rico em história da arquitetura das cidades neolíticas, gregas, romanas, pré-colombianas, islâmicas e medievais. O texto prioriza as artes visuais, com imagens do Partenon, fotos do Cairo, da Caaba e das catedrais de Pisa e Notre-Dame. O autor do capítulo, Fábio Cardoso, propõe uma atividade de comparação entre os estilos arquitetônicos românico e gótico.

Um pôster do filme "Spartacus" abre o capítulo "3.2. Relações culturais nas sociedades grega e romana na antiguidade: mulheres, plebeus e escravos". Cardoso pede ao estudante para observar o pôster do filme e pergunta: qual o tipo de representações lhe sugere o personagem Spartacus? Diz o autor: "os sujeitos oprimidos, ao longo da história, foram representados na historiografia, na literatura, nos meios de comunicação de massa, nos livros didáticos de várias formas, mas geralmente predominaram as representações produzidas pelas classes dominantes". O capítulo contem um texto intitulado "Imagens da mulher grega nas artes", ilustrado com a "Estátua grega de Helena", do séc. V a.C.; "Helena de Tróia", óleo sobre tela de Evelyn de Morgan; pôster de Helena no filme Troy, de 2004. Para as atividades, Cardoso solicita aos alunos uma "análise das imagens" da mulher grega nas artes. Uma estela funerária em mármore ilustra o texto "As mulheres na sociedade romana". Em alto relevo, a mulher está representada com a cabeça coberta por um véu, motivo que leva Cardoso a solicitar ao aluno que 
observe a imagem e escreva sobre a condição das mulheres na sociedade romana e suas possibilidades de resistência ao poder patriarcal.

O capítulo "3.3. Relações culturais nas sociedade medieval européia: camponeses, artesãos, mulheres, hereges e doentes", de Sueli Dias, contem artes visuais sob variadas formas, iluminura, pintura, gravura e afresco: "Trabalho dos servos num feudo" (iluminura, c. século XV); "Jacquerie: a batalha de Meaux" (iluminura, séc. XIV); "a Bastilha em Paris" (gravura, 1719); "Alegoria do bom governo" (afresco de Lorenzetti, c. 1337-1340); "Fiandeiras de seda" (iluminura, c. séc. XII); "Cena da Inquisição", gravura de Goya (1816); "Doctor Schnabel em Roma", gravura de 1656, alusiva ao médico, com roupa protetora anti-peste, em época de peste negra; e um retrato de Boccacio, autor de "Decameron" (1353), que contem um dos maiores relatos da peste em Florença.

Marli Francisco inicia o capítulo "3.4. Movimentos sociais, políticos, culturais e religiosos na sociedade moderna" com quadros chocantes: uma iluminura (c. séc. XIV) da "Jacquerie" e um óleo sobre tela de "O dia do Massacre de São Bartolomeu", de Dubois. O "Retrato de Martinho Lutero", óleo sobre tela, de Cranach, e a gravura "A Guerra dos camponeses" (a nobreza recebeu o apoio de Lutero, contra os camponeses) fazem parte do texto "Reforma Protestante e o fim do monopólio religioso da Igreja Católica. Com desenho de Cochin e ornamento de Prévost, o frontispício da Encyclopedie está carregado de simbolismo. A figura do centro representa a verdade - rodeada por luz intensa (o símbolo central do iluminismo). Duas outras figuras à direita, a razão e a filosofia, estão a retirar o manto sobre a verdade. Francisco solicita ao aluno que observe a imagem da Encyclopedie e faça uma leitura, inserindo-a no contexto de sua produção.

“3.5. Urbanização e industrialização no século XIX”. Altair Bonini abre o capítulo com o quadro de "Londres no início da Revolução Industrial". Ainda sobre Londres antiga, três xilogravuras: "Bairros pobres de Londres" e "Uma rua de bairro pobre de Londres", ambas de Gustave Doré, e "Vista a vôo de pássaro do boulevard Richard Lenoir". Um retrato do "Palácio de Cristal", de Londres, marco da arquitetura das cidades industriais, ilustra o texto "A arquitetura do século da indústria". Bonini solicita uma pesquisa de imagens em revistas, cartões postais, fotografias de grandes cidades, como Tóquio, Nova York, São Paulo ou Curitiba, principalmente de suas avenidas e edifícios: "descreva como você percebe a arquitetura destas cidades". "Compare estas imagens pesquisadas com a imagem do Paládio de Cristal, construído em Londres, em 1851". Uma pequena seção intitulada "Arte iconográfica" conduz o aluno até as principais obras realistas e impressionistas, como "As respigadeiras", óleo em tela (1857) de Millet, e "Estação do trem: o trem da Normandia", (1877) óleo sobre tela de Monet. A atividade em torno destas obras envolve elementos específicos da pintura (cores, planos, tema, forma, personagens, movimento artístico, etc.) e suas relações com o contexto histórico.

Para o capítulo "3.6. Movimentos sociais, políticos e culturais na sociedade contemporânea: é proibido proibir?", Bonini selecionou charges, fotografias, desenhos e cartaz, em torno de temas sociais: um cartaz da concentração dos moradores de bairro de Curitiba; o símbolo da paz/movimento hippie; fotos de Luther King e emblema do movimento negro; fotos de São Paulo, Cairo e Berlim; fotos do lixão de Curitiba e da Cooperativa dos Catadores de Papel de Apucarana; fotos de arquitetura da Índia e de Brasília (Niemeyer, Costa e Corbusier), luta pela terra e problemas sociais urbanos, com charges de Henfil. Como atividade: qual a crítica que a charge de Henfil faz em relação às representações que os latifundiários fazem da reforma agrária? produza uma charge representando a sua opinião sobre a reforma agrária e o Movimento Sem-Terra. Um dos textos sobre as artes reserva um espaço especial para a arte visual, sob o título "O rap e o 
movimento hip hop", incluindo um tema especial intitulado "Graffiti e educação" (Projeto Quixote, na zona sul de São Paulo, ligado à USP e iniciado em 2001).

Em "3.7. Urbanização e industrialização na sociedade contemporânea", Sueli Dias abre o capítulo com uma charge de Henfil sobre o espaço urbano e pergunta: "o espaço urbano produzido pela sociedade contemporânea gerou benefícios e problemas. Existe a possibilidade de solucionar os problemas sociais, econômicos, ambientais e sociabilizar os benefícios desta produção?" Várias imagens ilustram a explosão urbana, a relação entre tecnologia, urbanização e arte, e problemas sociais e estruturais na explosão urbana: vistas gerais de São Paulo e Cairo; ruínas do Reichstag, em Berlim; Assembléia de Chamdigarh (Índia); Congresso Nacional em Brasília; Lixão da Cachimba (Curitiba); cooperativados dos Catadores de Papel de Apucarana, recolhendo material reciclável em um colégio estadual da cidade; uma charge de Miguel Paiva sobre o direito à moradia e alimentação. Dias solicita ao estudante a organização de um debate em sala para discutir sobre as condições e organização dos locais de lazer e cultura de sua cidade. Em seguida, o aluno deve divulgar as críticas e sugestões. Para a pesquisa, solicita a organização de um dossiê sobre Brasília, com os resultados da pesquisa sobre os idealizadores do projeto de construção da cidade e o desenho da concepção original. Que pesquisem também outras obras de arquitetura do estilo moderno.

\section{Teatro}

Bonini, autor do capítulo "1.1. Conceito de trabalho", propõe uma atividade que sensibiliza, esteticamente, os alunos, em torno das contradições do trabalho, sob o capitalismo tardio. Sob o tema "O mundo do trabalho vai acabar?", a atividade solicitada é a montagem dramática, a partir de um texto extraído da obra "A agonia do emprego", de José Pastore. Está assim formulada: "com base no texto, organizem-se em grupo e elaborem uma dramatização sobre a constante utilização das máquinas na substituição do trabalho humano. Depois, apresentem para a sala". Em todo o livro didático, é a única proposta de dramatização.

No capítulo "1.2. O mundo do trabalho em diferentes sociedades", há poucas passagens alusivas ao teatro. Cardoso apenas menciona a "Poética", de Aristóteles. No texto "Tornar-se homem", Cambiano faz alusão às "Vespas", de Aristófanes, principal representante da comédia antiga. Nesta peça, há diálogos em torno da escravidão.

Não há conteúdo de teatro no capítulo "1.3. A construção do trabalho assalariado", de Sueli Dias. No entanto, na primeira página do capítulo, há um ensejo para a dramatização, a partir de dois desenhos que valorizam o gesto. $O$ primeiro desenho retrata um cidadão da antiguidade segurando um saco de sal, palavra que expressava valor e, etimologicamente, deu origem à palavra salário. O segundo desenho retrata uma pessoa puxando para fora os bolsos vazios, sinal de falta de dinheiro, o que sugere também carestia, baixos salários e, mesmo, ausência de salário, desemprego, expropriação...

Em "2.4. O Estado imperialista e sua crise", comenta-se que a peça "O Mercador de Veneza", de Shakespeare, foi apresentada constantemente, durante os regimes nazista e fascista. No texto intitulado "A arte nos regimes totalitários na Alemanha e Itália", os autores, Bonini e Francisco, comentam que o teatro, o cinema, a música, a arquitetura, a pintura, a fotografia e os símbolos eram utilizados para fins de propaganda.

Para a atividade dos alunos, sob o texto "A indústria cultural e as nações imperialistas", pede-se para citar exemplos da indústria cultural. Os autores não fazem referência explícita ao teatro, porém o termo indústria cultural é suficientemente amplo, o que motiva os alunos a percorrer todas as artes. Solicita-se ao aluno uma atividade em 
torno dos "hábitos culturais", o cinema e a linguagem. O aluno deve ler o texto 2 - trecho de "Imperialismo e cultura", de Octávio Ianni - e construir "uma narrativa histórica sobre a indústria cultural como meio para justificar a dominação do Estado imperialista sob os povos dominados". Em outra atividade, os autores propõem que o aluno perceba a influência dos produtos culturais das nações estrangeiras em nosso país. "Tais produtos podem alterar os hábitos culturais de parte da população (principalmente os jovens). Citem exemplos de filmes, moda, linguagem, música, e suas influências na sociedade brasileira."

Para o capítulo "3.2. Relações culturais nas sociedades grega e romana na antiguidade: mulheres, plebeus e escravos", Cardoso recorre aos diálogos de "A República", de Platão, e de "A greve dos sexos (Lisístrata): a revolução das mulheres", do comediante Aristófanes (nesta peça, as mulheres fazem greve de sexo para forçar atenienses e espartanos a estabelecerem a paz).

Em “3.7. Urbanização e industrialização na sociedade contemporânea", o estudante entra em contato com teatro, na seção "A tecnologia, a urbanização e a arte". Sueli Dias pede ao aluno para estudar um texto de Hobsbawm, extraído da "Era dos extremos". Citando Hobsbawm, Dias diz que o público de teatro e ópera, os leitores dos clássicos de literatura, poesia e prosa, e os visitantes de museus e galerias de arte, na segunda metade do século XX, pertenciam esmagadoramente aos que tinham pelo menos educação secundária. Pelo surgimento da "indústria da diversão de massa", as formas tradicionais da grande arte foram confinadas a "guetos de elite". O aluno deve produzir uma narrativa sobre a cultura transmitida pela indústria de diversão em massa. No debate, ele discute as condições e organização dos locais de lazer e cultura da cidade, incluindo os espaços teatrais. As críticas e sugestões devem ser divulgadas.

\section{Dança}

A dança estaria excluída do livro didático público "História: ensino médio", do Paraná, não fosse o minúsculo espaço aberto por Altair Bonini e Sueli Dias para essa arte.

No “3.6. Movimentos sociais, políticos e culturais na sociedade contemporânea: é proibido proibir?", três textos fazem alusão direta ou indiretamente à dança: "A contestação dos jovens pela música", "Movimento hippie" e "O rap e o movimento hip hop". Bonini comenta sobre o break, dança de rua, como um dos três elementos do hip hop (os outros são o rap e o graffiti). Porém, há controvérsias sobre a relação entre o rap e o hip hop. Segundo alguns estudos, o hip hop não pode ser confundido com o rap, devido a suas estruturas divergentes, em vários pontos, apesar dos pontos em comum. Bonini solicita ao aluno uma narrativa sobre a indústria cultural, comparando rock e hip hop.

$\mathrm{O}$ rock possui, historicamente, expressões que conduziram à dança. O rock progressivo influenciou gêneros de dança, como a dance music. Quanto ao tropicalismo, Bonini não se esquece de registrar um fenômeno da dança, ao afirmar que "os tropicalistas propunham uma mistura de estilos artísticos antigos e modernos, representados, por exemplo, pelas músicas regional, brega, samba, bolero e rock'n'roll'. Todas essas modalidades tem suas variantes musicais e dançantes.

No capítulo "3.7. Urbanização e industrialização na sociedade contemporânea", Sueli Dias, formula uma atividade, sob o tema "A tecnologia, a urbanização e a arte", pedindo ao aluno para analisar um texto de Hobsbawm e, depois, discutir com o professor e os colegas. A autora não faz referência explícita à dança, porém, Hobsbawm faz referências aos "guetos de elite" em que foram reduzidos o teatro e a ópera, gêneros em que a dança ocupa um lugar primordial (sobre o declínio da "grande arte", em 
geral, a "guetos de elite", veja os comentários, na seção anterior, "Teatro"). O aluno deve produzir uma narrativa sobre a cultura transmitida pela indústria de diversão em massa. A pesquisa inclui uma comparação entre o rock e o hip hop, que possuem movimentos de dança: "Quando e onde surgiram? Que grupos protagonizaram estes estilos? Que temas e mensagens transmitem?" No debate, o aluno discute as condições e organização dos locais de lazer e cultura da cidade. As críticas e sugestões da turma devem ser divulgadas.

\section{Cinema}

Tal como a dança, o filme também estaria radicalmente banido do ensino da história, no livro didático público do Paraná, não fossem os poucos comentários sobre dois documentários e um texto sobre filme-propaganda dos regimes fascista e nazista.

No capítulo "1.2. O mundo do trabalho em diferentes sociedades", de Fábio Cardoso, o estudante toma conhecimento do documentário em vídeo "Machu Picchu: na trilha dos incas", 1990, coordenação de Sílvio Martins. O documentário relata uma viagem pelas antigas cidades incas. Como atividade, o estudante deve assistir ao documentário e fazer um relato sobre os contextos sócio-históricos que determinaram as transformações e permanências em relação aos respectivos modos de vidas dos Incas pré-colombianos e de seus descendentes nos séculos XX e XXI.

O texto "A arte nos regimes totalitários na Alemanha e Itália" é parte do capítulo “2.4. O Estado imperialista e sua crise", de Altair Bonini e Marli Francisco. Os autores comentam que milhares de filmes de curta e longa metragem foram produzidos, sob os regimes fascista e nazista, com o objetivo de fazer propaganda dos regimes. Alguns filmes atacam diretamente os judeus e os comunistas, como "O eterno judeu" e "O jovem hitlerista Quex", ambos de 1940. Entre os filmes que tratam do heroísmo do espírito alemão, da bravura e do patriotismo, estão os dirigidos pela cineasta Leni Riefenstahl (1902-2003), como "O triunfo da vontade", de 1934, e "Olympia", de 1936. Como atividade, o estudante conversa com seus colegas de classe e escreve uma narrativa histórica sobre como a cultura se tornou um recurso importante para os regimes totalitários. Uma outra atividade está associada ao texto "A indústria cultural e as nações imperialistas", em que os autores inserem um trecho de "Imperialismo e cultura", do sociólogo Octávio Ianni. Os alunos devem perceber a influência de produtos culturais de nações estrangeiras em nosso país, pois eles "podem alterar os hábitos culturais de parte da população (principalmente os jovens)", e citar exemplos de filmes, além de moda, linguagem e música, e suas influências na sociedade brasileira.

"Spartacus", de Kubrick, é o filme selecionado para o capítulo “3.2. Relações culturais nas sociedades grega e romana na antiguidade: mulheres, plebeus e escravos". Fábio Cardoso recomenda que o aluno assista ao filme e compare suas representações com as representações contidas no texto.

Como já dito, acima, nas seções de todas as artes, o capítulo “3.7. Urbanização e industrialização na sociedade contemporânea" contem uma atividade que aplica-se a todas as artes, sob o tema "A tecnologia, a urbanização e a arte". Sueli Dias pede aos estudantes para analisar um trecho extraído do capítulo "Morre a vanguarda: as artes após 1950", da obra "Era dos extremos: o breve século XX", de Hobsbawm (sobre o declínio da "grande arte", em geral, a "guetos de elite", veja os comentários, na seção, acima, sobre "Teatro"). Após a leitura do texto e a discussão com o professor e os colegas, cada aluno deve produzir uma narrativa sobre a cultura transmitida pela indústria de diversão em massa. Para o debate, a autora propõe uma discussão sobre as condições e organização dos locais de lazer e cultura da cidade dos alunos e a divulgação das críticas e sugestões 
formuladas pelos estudantes. Em todas essas atividades e debates propostos, não há referência explícita ao cinema e o filme. Está implícito, no entanto, que um dos locais de lazer e cultura da cidade é o cinema, seja como local (a sala pública, coletiva), seja como modo de projeção cinematográfica, no sentido tradicional do projetor colocado atrás da platéia. Outro local, preferido pelos jovens, está escondido nos recônditos privados da família, com TV, hometheater, DVDs, telões e internet.

\section{A AUSÊNCIA DA MÚSICA NO ENSINO DA HISTÓRIA}

Os professores de história que desejam valorizar a relação entre música e sociedade encontram, no livro didático público "História: ensino médio", do Paraná, apenas um pequeno texto direcionado para a música. Esta única escolha musical contida no livro vale pela abordagem interdisciplinar de música e política, música e ideologia, possibilitando interessantes elos explicativos entre música e sociedade. Bonini, autor do capítulo “3.6. Movimentos sociais, políticos e culturais na sociedade contemporânea: é proibido proibir?", não se deixa levar apenas pelas letras das canções. Ele faz incursões políticoideológicas sobre a estruturação das melodias, ritmos, harmonia e instrumentação, como a substituição do violão acústico pela guitarra elétrica, nos movimentos da juventude.

O referido livro didático não encara a canção como arte dos sons. Ele confunde música com letra das canções, chama um poema de canção, não sugere nenhuma atividade de natureza exclusivamente musical e exclui a música da canção. Se se pretende trabalhar a sensibilidade no plano da educação estética completa (omnilateral) do potencial humano, não pode ser excluído aquele mínimo de atividades que somente a música propicia. Há uma afetividade peculiar aos movimentos musicais da juventude, desde as baladas mais conservadoras às politizadas, envolvendo ritmo, percussão, dança e canto coletivo, atividades populares tão difusas, de execução relativamente fácil, em qualquer sala de aula. A afetividade que gera coesão entre jovens, em suas "tribos", através da música, tem sido tema de pesquisas avançadas, desde que o conceito de afetividade como característica principal da música popular foi desenvolvido, nos anos 1990, por Grossberg. A característica principal da música popular consiste em conduzir seu público a um espaço afetivo. O afeto não é puramente físico ou emocional, mas também age em sentido social, como uma forma de capital cultural que contribui para a formação dos gostos culturais (SHUKER, 1999: 16), tanto para a dominação quanto para a emancipação humana.

Movimentos musicais da juventude são comentados por Bonini, sob o título geral "A contestação dos jovens pela música", sobre a música de protesto, o rock dos anos 60, tropicalismo e, posteriormente, o rap. Já o texto "Movimento hippie" não tem nenhum conteúdo de música, não faz alusão ao rock, nem às afinidades entre o movimento hippie e os movimentos musicais da "contracultura". Como o livro didático não recorre a nenhuma obra geral de história da música, limitamo-nos, aqui, a um lembrete em torno do movimento hippie. Este juntou-se a movimentos de protest song, a exemplo da folkmusic de Joan Baez, inserida no DVD "Diário de Woodstock: sexta-feira - 15 de agosto de 1969". O professor pode solicitar que os alunos acessem o youtube, onde foram inseridos interessantes clipes de Joan Baez e outros cantores, no Festival de Woodstock (tais vídeos foram inseridos no youtube, recentemente, após 2006, ano da edição do livro didático público de História, do Paraná). Baez foi um ídolo tanto de jovens radicais quanto de hippies, de fãs de música folk e do rock psicodélico inspirado na folk music. O rock psicodélico relaciona-se tanto com a contracultura, cujas diversas tendências incluem letras "quase" revolucionárias, quanto com a corrente hippie. 
No estudo "Problemas da história sem música e musicologia sem história" afirmávamos que ainda estavam sendo iniciados os estudos, em história social, dos principais modelos teóricos e respectivas práticas da modernidade musical brasileira (GIANI, 1997). No entanto, quando a música está presente, nos livros de história e livros específicos de história da música, é comum faltar-lhe a base social, que o historiador costuma omitir. No ensaio "Papel da arte na educação: o que os PCN não dizem sobre a relação entre arte e sociedade de classes sociais" (GIANI, 2006), o título já explicita o problema... Se a história social da música brasileira ainda não deu conta do seu próprio ofício, não é de se estranhar que a disciplina história contenha grandes vazios, uma vez que estes decorrem de fraquezas de ambas as partes.

É importante, em estudos político-ideológico-musicais, que seja desvelada a história social sob todos os aspectos, sem exclusão dos aspectos estritamente musicais, aqueles que não envolvem palavras, letras. As ideologias também atravessam a estética musical e suas práticas, como as partituras das composições. A ausência das partituras em pesquisas de história social da música é um aspecto criticado em "Sons de história", de Marcos Silva (SILVA, 2002).

Sobre as históricas doutrinas estéticas que cercam a música orquestral brasileira, um dos primeiros estudos mais significativos, em torno da relação música/ideologia, foi escrito pelo historiador e musicólogo Arnaldo D. Contier: "Música e ideologia no Brasil", publicação que reúne um ensaio de 1975 e, outro, de 1980 (CONTIER, 1985). Desde então, outras pesquisas envolvendo o tema foram realizadas, como a tese de doutorado "Música contemporânea brasileira" (1976), de José Maria Neves; "O Coro dos contrários: a música em torno da semana de 22" (1977), de José Miguel Wisnick; "O Nacional e o popular na cultura brasileira: música" (1982), de Ênio Squeff e José Miguel Wisnik; “A música de protesto" (1985), dissertação de mestrado, de Luiz Giani; "Uma odisséia musical" (1994), de Gilberto Mendes; uma seção sobre música, na obra "O imaginário vigiado: a imprensa comunista e o realismo socialista no Brasil" (1994), de Denis de Moraes; "As trombetas anunciam o paraíso. Recepção do realismo socialista na música brasileira", de Luiz Giani (tese de doutorado, 1999); "Música viva e H. J. Koellreutter: movimentos em direção à modernidade" (2001), de Carlos Elias Kater; e a dissertação de mestrado "O Debate no campo do nacionalismo musical no Brasil (anos 40 e 50): o compositor Guerra Peixe" (2004), de André Acastro Egg., entre outros trabalhos voltados parcial ou integralmente para as relações entre música e ideologia, especialmente, no gênero para orquestra, câmera, instrumentos solistas e coral.

De um modo geral, os resultados dessas pesquisas mal chegaram ou não chegaram aos compêndios e livros didáticos de história. Assim, não é de se estranhar que a música sinfônica não faça parte do "Universo das artes" (capítulo 3 de "Convite à filosofia"), de Marilena Chauí. No referido texto, Chauí não faz referência a qualquer movimento musical sinfônico, na posição em que são mencionados o teatro de Brecht e Boal, a poética de Maiakovski, Neruda, Gullar e Paes, a literatura de Sartre e Graciliano Ramos, o cinema de Eisenstein, Chaplin e Glauber Rocha, a pintura de Picasso e Portinari:

Por estabelecer uma relação intrínseca entre arte e sociedade, o pensamento estético de esquerda também atribui finalidade pedagógica às artes, dando-lhe a tarefa de crítica social e política, interpretação do presente e imaginação da sociedade futura. A arte deve ser engajada ou comprometida, isto é, estar a serviço da emancipação do gênero humano, oferecendo-se como instrumento do esforço de libertação.

Essa posição foi defendida pelo teatro de Brecht e, no Brasil, pelo de Augusto Boal; pela poesia de Maiakovski e Pablo Neruda, e, no Brasil, 
pela de Ferreira Gullar e José Paulo Paes; pelo romance de Sartre, e, no Brasil, pelo de Graciliano Ramos; pelo cinema de Eisenstein e Chaplin, e, no Brasil, pelo Cinema Novo; pela pintura de Picasso e, no Brasil, pela de Portinari; na música, pela chamada música de protesto - no Brasil, a música popular dos anos 60 e 70, foi de protesto político, com Edu Lobo, Chico Buarque, Caetano Veloso, Gilberto Gil, Geraldo Vandré, Milton Nascimento, entre outros. (CHAUÍ, 1997: 324-325)

Edu Lobo, Chico Buarque, Caetano Veloso, Gilberto Gil, Geraldo Vandré e Milton Nascimento não representam a música de concerto, por não serem compositores para orquestra. Para orquestração de suas músicas, geralmente, são convidados grandes mestres da composição orquestral. A história da música popular-urbana "engajada", "comprometida", "de protesto", como a história da música popular, em geral, nacional e universal, pode ser preenchida pelos professores de história e de arte, pois, já existe uma relativa fartura bibliográfica, no gênero. Porém, algo diverso acontece com a música orquestral.

A ausência da música nos livros didáticos de história torna-se mais grave, quando se trata do gênero de música para orquestra, câmera, coro e instrumentos solistas, pois este gênero envolve normas de composição sobre partituras, em cursos de graduação em Composição e Regência ou iniciativas isoladas, de autodidatismo, que exigem do estudante de composição um enorme esforço, dedicação, e aulas particulares com os "mestres". Neste gênero, as relações entre música e ideologia, tal como na música popular-urbana, forma-se um campo de contradições e conflitos sociais e político-ideológicos. Como observou Hobsbawm, a música foi confinada, sob o capitalismo tardio da segunda metade do século XX, a um "gueto de elite". Por sua vez, Bourdieu não estava enganado, quando afirmou que "não existe prática mais classificatória, mais distintiva, isto é, mais estreitamente ligada à classe social e ao capital escolar possuído do que a frequiência a concertos (...) para compreender que o concerto estava predisposto para se tornar uma das grandes celebrações burguesas. (BOURDIEU, 1983: 123). Entre os conflitos políticoideológicos, no campo da música de concerto, surgiram várias tentativas históricas com o objetivo de demolir a música como "celebração burguesa".

Um breve período da história da música sinfônica e seus elos político-ideológicos é tema para as reflexões que se seguem.

\section{SINFONIA E IDEOLOGIA: DESAFIOS PARA O ENSINO DA HISTÓRIA}

No Brasil, tal como nos países em que o Partido Comunista se fizesse presente, uma grande polêmica instaurou-se entre os militantes e simpatizantes do partido divididos entre movimentos musicais conflitantes, após a segunda guerra mundial: música progressista, de um lado, e, música de vanguarda, de outro.

Críticos de arte de tendência trotskista, como Mário Pedrosa, saíam em defesa das inovações estéticas, como o serialismo, a música dodecafônica, a música concreta e, mais tarde, o tropicalismo. Contra o serialismo e sua variação dodecafônica, formou-se um verdadeiro campo de batalha estética, ideológica e política, no Brasil. Na URSS e países comunistas do Leste, a polêmica era agravada pelas perseguições, censuras, proibições, condenações...

Na Escola de Frankfurt, Adorno defendia o serialismo dodecafônico como negação da totalidade social, conquanto o serialismo não se transformasse em epigonismo conservador. Desde então, críticas rigorosas foram endereçadas a Adorno, como nos argumentos de Mészáros, contra a filosofia da música, base da "dialética negativa", de 
Adorno. Mészáros incluiu reflexões sobre música, no capítulo "A teoria crítica de Adorno e Habermas", da obra "O poder da ideologia" (MÉSZÁROS, 1996: 129-130).

A música orquestral "engajada", música "progressista", contou com a participação de compositores, regentes e instrumentistas de larga formação acadêmica, de tendência de esquerda, como Cláudio Santoro, Camargo Guarnieri, Mignone, Koellreutter, GuerraPeixe, José Siqueira, Eunice Katunda, Edino Krieger, Geni Marcondes, Rogério Duprat, Arnaldo Estrella e Oscar Borgeth, alem de críticos de música, como Ênio Silveira, para citar apenas alguns dos envolvidos na querela, na década de 1950. Mário de Andrade já havia falecido. Oswald de Andrade, em guerra com o realismo socialista, sai das fileiras do PCB. O movimento autodenominou-se de "música progressista", uma fusão de estética nacionalista com estética do realismo socialista de origem soviética, em oposição às estéticas musicais chamadas de "vanguardas". O serialismo dodecafônico era acusado de abstracionismo, expressionismo em música, "expressão da burguesia decadente".

O movimento musical de compromisso político-ideológico, na música de concerto, iniciou-se antes mesmo do surgimento do Cinema Novo e da música de protesto popularurbana. Com o término da segunda guerra mundial, iniciou-se a guerra fria e, dentro desta, a URSS retomou a perseguição às vanguardas atonalista e serialista-dodecafônica. Esta guerra, no campo da música, remontava aos anos 30, quando o governo soviético deu início à doutrina do realismo socialista. Nos anos 1940/1950, a ideologia do sinfonismo socialista, no Brasil, era praticamente importada, fundada em princípios estéticos do realismo socialista soviético que se acasalaram com a estética musical nacionalista. $\mathrm{O}$ principal teórico do nacionalismo musical, Mário de Andrade, pouco antes do seu falecimento, escreve um prefácio intitulado "Chostakovich" (1945), onde faz elogios à música soviética, imaginando que tal música fosse a expressão de uma sociedade sem classes sociais (GIANI, 1997).

O conflito entre vanguarda revolucionária e vanguarda estética surgiu no período entre guerras, por conta dos debates travados, especialmente, no interior dos partidos comunistas. Tais como as inovações formais de Picasso, as inovações em música colocavam o partido comunista contra seus próprios membros e simpatizantes que aderissem à estética radical vanguardista. Uma pedra no sapato do realismo socialista tanto podia advir das ousadias de "Guernica" (Picasso), quanto de um concerto dodecafônico de Shoenberg ou de uma ópera, como "Lady Mcbeth de Mtsensk" (Shostakovich) que, após ser acolhida por dois anos pelo público soviético, foi suspensa e condenada pelo governo de Stálin (para ouvir a obra, inserimos dois sites, ao final deste ensaio). Koellreutter, seguidor do dodecafonismo, introduziu esta escola no Brasil e, sob a guerra fria e os ataques zdhanovistas, foi condenado na imprensa comunista como falsário e traidor.

Ambas as correntes em guerra, progressismo e vanguardismo, atribuíam, cada uma para si, a exclusividade de música "revolucionária" e de verdadeiro caminho da arte para a construção do socialismo. Nesse antagonismo, uma pendia para a tradição, com inclinações folcloristas, românticas e neoclássicas, e a outra, para a inovação formal. As inclinações folcloristas, neoclássicas e românticas da música progressista, fundadas em utopias simultaneamente nacionalistas e marxista-soviéticas, colocavam os compositores, como os soviéticos Shostakovich e Katchaturian e o brasileiro Cláudio Santoro, filiado ao PCB, na linha doutrinária do realismo socialista.

Os professores de história já podem acessar, na internet, um precioso repertório musical relacionado com o período em questão, embora o repertório seja ainda pequeno, pois sua inserção no youtube é muito recente. Ainda há muito por vir, brevemente... Um clipe de "Spartacus" (1954), suite de bailado do soviético Khatchaturian, está disponível. Basta acessar "Adágio de Spartacus e Frígia" (clique no site, ao final deste ensaio). 
Entre as obras pioneiras, de cunho nacionalista e tendência ideológica socialista, no período entre-guerras, está a "Sinfonia do trabalho", de 1939 (originalmente chamada de "Sinfonia proletária"), de Francisco Mignone. O leitor pode acessar outra obra significativa de Mignone, disponível no youtube: "Maracatu do Chico Rei" (1933), à qual o compositor imprimiu profundo espírito nacionalista (após a guerra, Mignone ingressará no Partido Comunista). Para ouvir a obra, acesse o respectivo site, ao final deste ensaio.

Já estão disponibilizados, no youtube, alguns clipes de música "progressista" brasileira, do período pós-segunda guerra mundial, até o início do governo JK: "Sinfonia da Paz" (n.4), de 1953, de Santoro (há uma gravação desta obra, pela Orquestra Sinfônica do Estado da URSS, sob a regência do compositor); "El Negro mar", de Krieger, de 1953, sobre poema do poeta cubano Nicolas Guilhén (a música de Krieger atendeu a uma encomenda de Carlos Prestes para a recepção ao poeta, que visitava o Brasil); "Prólogo e fuga", de 1947, é de Guarnieri, (que fez várias visitas à URSS); "Mourão" (1950, aproximadamente), de Guerra-Peixe (também teve obras orquestrais gravadas pela Orquestra Estadual de Moscou). O leitor pode acessar as referidas obras, clicando nos respectivos sites, ao final deste ensaio.

Pela "Música de Vanguarda" e "Música Viva", difundiram-se estéticas musicais de origem européia, como o dodecafonismo, de Shoenberg a Luigi Nono (membro do Partido Comunista Italiano), e de Koellreutter, introdutor da escola dodecafônica e fundador do "Música Viva", no Brasil. A "música concreta" dava seus primeiros passos, na França, com Pierre Schaeffer, e, no Brasil, com os primeiros ouvintes (entre eles, Haroldo e Augusto de Campos e Décio Pignatari) das gravações de John Cage, nos anos 50. Nos anos 60 , ocorreram as primeiras experiências brasileiras com música concreto/eletrônica, como as de Jorge Antunes, e novos movimentos, como o "Música Nova", contemporâneo da música de protesto popular-urbana. Esta, por sua vez, despontava no cancioneiro de Vandré, Edu Lobo, Carlos Lira, Tom Jobim, Vinicius de Moraes, Gianfrancesco Guarnieri, Chico Buarque, Vianinha, Boal, Milton Nascimento, Caetano, Gil, Nara Leão, Maria Bethânia, João do Vale e Zé Kéti, entre muitos outros.

Os pesquisadores e professores de história não músicos enfrentam maiores dificuldades no trato das questões ideológicas relacionadas com sistemas musicais complexos, como o atonalismo e o dodecafonismo (o compositor inventa uma série de 12 sons, não repete nenhum som antes de percorrer toda a série e trabalha com a série de forma muito variada e complexa). Já estão disponíveis várias obras na internet, em execução orquestral, como as "Cinco peças para orquestra opus 16", uma das primeiras obras atonais de Schoenberg, de 1909. Entre as obras dodecafônicas de Shoenberg, está o "Concerto para piano op. 42". O leitor pode clicar nos respectivos sites dessas obras, ao final deste ensaio, para ver e ouvir.

De Koellreutter, introdutor do dodecafonismo no Brasil, não encontramos nenhuma obra dodecafônica de sua autoria, no youtube. Entre as obras brasileiras baseadas na série dodecafônica, está a interpretação da Orquestra à Base de Sopro, executando "Office boy", do curitibano Arrigo Barnabé. Do mesmo compositor, "Clara Crocodilo" não é dodecafônica, mas "modular", conforme a entrevista com o compositor. Na mesma entrevista, Barnabé interpreta um fragmento de "Office boy", ao piano (para acessar as obras, clique nos respectivos sites, ao final deste ensaio).

\section{CONCLUSÃO}

Este ensaio confirmou, mais uma vez, a timidez dos livros didáticos de história, nos usos da arte. Literatura e artes visuais exercem, quase, um domínio absoluto. Música, 
dança e cinema são grandes desconhecidos, ou quase, no livro didático público "História: ensino médio", do Paraná. Este livro é uma experiência de grande valia, que sinaliza uma preocupação e esforço louvável em torno do que Marx chamou de "homem omnilateral", total, universal. Esperamos que este ensaio seja útil como incentivo a todas as artes, na revisão do livro, bem como à revisão de outro livro didático do Paraná, o de "Arte: ensino médio", de modo que os professores de arte possam enriquecer ainda mais suas experiências com a metodologia da história social, da arte vista como produto e produtora da sociedade.

A educação politizada dos sentidos não é campo exclusivo das artes, mas, expressão da totalidade humana, da história dos homens, consequentemente, da ciência da história e sua pedagogia, sob todas as formas de ciência e arte.

As artes, em tempos de estetização da barbárie, sob o capitalismo tardio, tem uma função emancipatória a cumprir, começando pelo resgate de suas tentativas históricas de politização da própria arte. A humanidade pode superar ou, pelo menos, colocar limites imediatos no que Marcuse chamou de "repressão desnecessária" e no que Freud diagnosticou como sendo o vínculo entre Eros e Thanatos, o prazer e a morte. No capitalismo tardio, prazer e arte são formas de dominação para a satisfação dos contentes resignados, fenômeno que Benjamin já havia diagnosticado, nos anos 30, ao perceber que a humanidade estava vivendo a sua própria destruição, "como um gozo estético de primeira ordem", o gozo de sua própria morte.

Politizar a arte e estetizar o ensino da história do trabalho subjugado: é uma, entre muitas respostas...

\section{Referências bibliográficas}

BAUMAN, Zygmunt. Modernidade líquida. Rio de Janeiro: Jorge Zahar, 2001

BENJAMIN, Walter. A obra de arte na época de suas técnicas de reprodução. In BENJAMIN, Walter et alii. Textos escolhidos (Os pensadores, XLVIII). São Paulo: Abril Cultural, 1975, 9-34 BONINI, Altair. Conceito de trabalho. In História / vários autores. Curitiba: SEED-PR, 2006

Movimentos sociais, políticos e culturais na sociedade contemporânea: é proibido proibir? In História / vários autores. Curitiba: SEED-PR, 2006

Curitiba: SEED-PR, 2006 Urbanização e industrialização no século XIX. In História / vários autores.

BONINI, Altair e FRANCISCO, Marli. O Estado imperialista e sua crise. In História / vários autores. Curitiba: SEED-PR, 2006

BOURDIEU, Pierre. A origem e a evolução das espécies de melômanos. In Questões de Sociologia. Rio de Janeiro, Marco Zero, 1983

CARDOSO, Fábio de Oliveira. 3.1. As cidades na história. In História / vários autores. Curitiba: SEED-PR, 2006

O Estado e as relações de poder: formação dos estados nacionais.

In História / vários autores. Curitiba: SEED-PR, 2006

O mundo do trabalho em diferentes sociedades. In História / vários autores. Curitiba: SEED-PR, 2006

Relações culturais nas sociedades grega e romana na antiguidade:

mulheres, plebeus e escravos. In História / vários autores. Curitiba: SEED-PR, 2006

CHAUÍ, Marilena. Convite a filosofia. São Paulo: Ática, 1997, $8^{a}$ edição

CONTIER, Arnaldo Daraya. Música e ideologia no Brasil. $2^{\mathrm{a}}$ ed. rev. e ampl. São Paulo: Novas Metas, 1985

FESTIVAL DE WOODSTOCK. Diário de Woodstock: sexta-feira - 15 de agosto de 1969 (DVD) 
DIAS, Sueli. O trabalho na sociedade contemporânea. In História / vários autores. Curitiba: SEED-PR, 2006

SEED-PR, 2006

O Estado nos mundos antigo e medieval. In História / vários autores. Curitiba:

Relações culturais nas sociedades medieval européia: camponeses, artesãos, mulheres, hereges e doentes. In História / vários autores. Curitiba: SEED-PR, 2006

Urbanização e industrialização na sociedade contemporânea. In História / vários autores. Curitiba: SEED-PR, 2006

FRANCISCO, Marli. Movimentos sociais, políticos, culturais e religiosos na sociedade moderna. In História / vários autores. Curitiba: SEED-PR, 2006

Curitiba: SEED-PR, 2006

Urbanização e industrialização no Paraná. In História / vários autores.

FRANCISCO, Marli e CANHA, Vanderleia. Transição do trabalho escravo para o trabalho livre: a mão de obra no contexto de consolidação do capitalismo nas sociedades brasileira e estadunidense. In História / vários autores. Curitiba: SEED-PR, 2006

GIANI, Luiz A. Mário de Andrade: da "Paulicéia desvairada" a Moscou: um encontro com Shostakovich. In Pós-história: revista de pós-graduação em história. Assis: Universidade Estadual Paulista, v. 5, 1997, 105-122

Música de protesto. D’O subdesenvolvido à Canção do bicho e Proezas de Satanás na terra do leva-e-traz... UNICAP/IFCH, dissertação de mestrado em sociologia, 1986, http://libdigi.unicamp.br/document/?code=000048247) / Acessado em: 11 jan. 2010

. Papel da arte na educação: o que os Parâmetros Curriculares Nacionais não dizem sobre a relação entre arte e sociedade de classes sociais. Máthesis; revista de educação. Faculdade de Filosofia, Ciência s e Letras de Jandaia do Sul. Vol. 6, n. 2 (jul/dez.), 2005, 9-50

Problemas da história sem música e musicologia sem história. Cadernos de

metodologia e técnica de pesquisa: revista anual de metodologia de pesquisa. Universidade Estadual de Maringá / Departamento de Fundamentos da Educação / Área de Metodologia e Técnica de Pesquisa. 1997, 89-126

As trombetas anunciam o paraíso. Recepção do realismo socialista na música brasileira. Assis: UNESP/Pós Graduação em História, tese de doutorado (digitada), 1999

HOBSBAWM, Eric. As artes 1914-45 / Morre a vanguarda: as artes após 1950. In A era dos extremos: o breve século XX, 1914-1991. São Paulo: Companhia das Letras, 1995, 178-197, 483503

MARCUSE, Herbert. "Prefácio político" (1966). In Eros e civilização: uma crítica filosófica ao pensamento de Freud. Rio de Janeiro: Zahar, 1968, 13-23

MARX, Karl. O Capital. Rio de Janeiro: Civilização Brasileira, Livro 1, v. 1, 1975

Manuscritos econômico-filosóficos. São Paulo: Martin Claret, 2006

MARX-ENGELS. Sobre literatura e arte. São Paulo: Global, 1979

MESZÁROS, István. A teoria crítica de Adorno e Habermas. In O Poder da ideologia. São Paulo: Ensaio, 1996, 129-190

NAPOLITANO, Marcos. Como usar o cinema na sala de aula. São Paulo: Contexto, 2008; também no site:

http://books.google.com.br/books?hl=pt-

BR\&lr=\&id=3KgUYhbvRKsC\&oi=fnd\&pg=PA7\&dq=marcos+napolitano+hist\%C $3 \%$ B3ria $+\mathrm{e}+\mathrm{m}$ \%C3\%BAsica\&ots=inq1izXULK\&sig=uXKQoWI3YJlt1Wt7glWF2ZQeM3Y\#v=onepage\&q=\&f =false / Acessado em: 03 mar 2010

OITICICA, Hélio. Brasil diarréia. In BRITO, Ronaldo e VENÂNCIO, Paulo. O moderno e o contemporâneo (O novo e o outro novo)... Rio de Janeiro: FUNARTE, 1980. Também no site:

http://www.itaucultural.org.br/aplicexternas/enciclopedia/ho/index.cfm?fuseaction=documentos\&c od=170\&tipo=2 Acessado em: 14 mar. 2010

SAGATI, Siumara. A construção do trabalho assalariado. In História / vários autores. Curitiba: SEED-PR, 2006

Relações de dominação e resistência no mundo do trabalho contemporâneo (séculos XVIII e XIX). In História / vários autores. Curitiba: SEED-PR, 2006 
SEED-PR, 2006

Relações de poder e violência no Estado. In História / vários autores. Curitiba:

SEED-PR, 2006

Urbanização e industrialização no Brasil. In História / vários autores. Curitiba:

SHUKER, Roy. Vocabulário de música pop. São Paulo: Hedra, 1999

SILVA, Marcos. Sons de história. In Entre passado e futuro - revista de História Contemporânea. São Paulo: Xamã, n. 2, set. 2002, 104-126

Sites

BARNABÉ, Arrigo. Arrigo Barnabé no Thunderview - Modulações de "Clara Crocodilo" e a performance do embrulho $\quad$ nos $\quad$ anos 8 . http://www.youtube.com/watch?v=OyGN8LP0G8w\&feature=related Acessado em: 11 jan. 2010

Arrigo Barnabé e Orquestra à Base de Sopro.

http://www.youtube.com/watch?v=QXDU2J534vM\&feature=related Acessado em: 14 mar. 2010

CAMARGO GUARNIERI. Camargo Guarnieri: Prologo e Fuga (1947)

http://www.youtube.com/watch?v=rW2k5jwS7fI Acessado em: 4 mar 2010

GUERRA-PEIXE, César. Guerra Peixe/Clóvis Pereira: Mourão/Osesp e Banda Mantiqueira

http://www.youtube.com/watch?v=XkdvGp_p8Gg Acessado em: 04 mar. 2010

HOBSBAWM, Eric. As artes 1914-45 / Morre a vanguarda: as artes após 1950. In A era dos extremos: o breve século XX, 1914-1991. São Paulo: Companhia das Letras, 1995, 178-197, 483503

KHATCHATURIAN, Aram. Adagio" from "Spartacus" (Aram Khatchaturian)

http://www.youtube.com/watch?v=86v05kSTZ3Y / Acessado em: 14 mar. 2010

KRIEGER, Edino. 34-Edino_Krieger_-_EI_Negro_Mar.wmv

http://www.youtube.com/watch?v=gr77hdu539o Acessado em: 04 mar. 2010

MIGNONE, Francisco. Mignone: Maracatu do Chico Rei/Osesp (Parte I)

http://www.youtube.com/watch?v=pJEyuQhzE-4 / Acessado em: 06 Jan. 2009

SANTORO, Cláudio. Santoro - Sinfonia no 4 ("Sinfonia da Paz") - I. Allegro

http://www.youtube.com/watch?v=ObtdAbSNF6M\&feature=related / Acessado em: 04 mar. 2010

SCHOENBERG, Arnold. Orchesterstuecke op. 161 of 2

http://www.youtube.com/watch?v=VPh9YOG776E\&feature=related / Acessado em: 14 mar 2010

Schoenberg Piano Concerto op. 42 (1/3)

http://www.youtube.com/watch?v=SkXO3ubAvdQ / Acessado em: 14 mar. 2010

SHOSTAKOVICH, Dmitri. Eva-Maria Westbroek, Lady MacBeth of Mtsensk, Shostakovich,

Na chulky

http://www.youtube.com/watch?v=bTvKk8uAWN0 / Acessado em: 15 mar. 2010

Shostakovich: Lady Macbeth of Mtsensk (Opus Arte)

http://www.youtube.com/watch?v=z9vNVV7LFCI / Acessado em: 15 mar. 2010

\footnotetext{
* Graduado em Ciências Sociais e Música/piano (UFRJ), mestre em Sociologia (Unicamp) e doutor em História (UNESP/Campus de Assis). Professor aposentado, do Departamento de Ciências Sociais da Universidade Estadual de Maringá, ministra a disciplina "Teoria crítica da sociedade", no programa de mestrado em Ciências Sociais. Este ensaio é um resultado de estudos teóricos e experiências em cursos de especialização em Arte-educação e, especialmente, na disciplina "Arte e didática da história", ministrada no curso de especialização em Metodologia e didática da história, da Faculdade Estadual de Educação, Ciências e Letras de Paranavaí. E-mail: luizgiani@yahoo.com.br
}

Recebido dia 30 de maio de 2010

Avaliado dia 07 de junho de 2010 